\title{
Inquiries-Based Learning Workshop One of Teacher Development to Improve the Quality of Learning in Santa Lusia Sei Rattan Private Junior High School
}

\author{
Listaran Sinurat $^{1, *}$ Arif Rahman ${ }^{2}$ Zulkfli Mantondang ${ }^{3}$ Fatima Sari Nasution ${ }^{4}$
}

\author{
${ }^{1}$ Universitas Negeri Medan, Medan, Indonesia \\ ${ }^{2}$ Universitas Negeri Medan, Medan, Indonesia \\ ${ }^{3}$ Universitas Negeri Medan, Medan, Indonesia \\ ${ }^{4}$ Universitas Negeri Medan, Medan, Indonesia \\ *Corresponding author. Email: listaransinurat74@gmail.com
}

\begin{abstract}
Inquiries based learning workshop one of teacher development to improve quality of learning in Santa Lusia junior high school. Teacher development research through inquiry-based workshops to improve the quality of learning in santa lucia sei rotan private junior high school aims to answer the problem of low quality. This type of research is school action research, which is a series of activities related to data collection methods through interviews, questionnaires, and documentation. Research on teacher development through inquiry-based learning model workshops shows that the quality of learning in schools is largely determined by the absolute competencies that teachers must possess and the selection of appropriate learning models. The role of educators becomes very vital because the progress of an educational institution is determined by the quality and capacity of the educators. One of the determining factors in improving the quality, especially the absorption of students as indicated by the acquisition of grades, is the learning process in the classroom carried out by the teacher. And to improve teacher professionalism which leads to improving the quality of learning in the classroom, it must be carried out in a planned manner.

Inquiry-based learning model workshop is one of the learning models that has been developed for the purpose of teaching students how to think creatively when facing problems or facing problems. Inquiry-based learning model workshops also stimulate students to think critically and creatively and in turn easily understand and master teaching materials well. In this regard, the process of fostering and developing educators becomes important and decisive in achieving the goals of quality school education. Coaching for educators is a strategic factor for improving the quality of education with various efforts in the context of developing integrated human resources.
\end{abstract}

Keywords: Teacher Development, Quality, Workshop, Inquiry Model, Learning.

\section{INTRODUCTION}

The development of science and technology causes changes in various aspects of life such as social, political, economic, and industrial aspects, especially in the field of education. Professional teachers are the determining factor in the quality education process. Law Number 14 of 2005 concerning Teachers and Lecturers (article 1) states that: "Teachers are professional educators with the main task of educating, teaching, guiding, directing, training, assessing and evaluating students in the formal education path, at the primary and secondary education levels." In line with that Saud (2012: 49) asserts that a professional teacher is a teacher who has a set of competencies (knowledge, skills and behavior) that must be possessed, internalized, and controlled by teachers in carrying out their professional duties.

The success of learning in schools cannot be separated from the absolute competencies that teachers must have to support their ability to teach as their duties. This is reinforced by the opinion of Sanjaya (2012: 13) which states that no matter how good and ideal the educational curriculum is, however complete the infrastructure is, without being balanced with the teaching ability of teachers in implementing it, everything will be less meaningful. Furthermore, Van Brumellen (2009) explains that the important focus for 
teachers in teaching is understanding, views, wisdom, which students want to achieve. Meanwhile, according to Senge (2000) defines the teacher as follows: ..., an expert who is capable of imparting knowledge that will help learning to build, identify and acquire skill that will be used to face the challenges in life. The teacher also profides to the learnes knowledge,skill and values that enhance development. An educated person is both private and public sectors. The educated person can easily secure employmen as well as having life skill that will enable $\mathrm{hi} /$ her to interect well in the society.

Based on the above understanding, the teacher is someone who has been equipped with the skills and knowledge to guide, build and direct students to the knowledge and skills according to their level of education. Thus the teacher plays a very important role in the progress of a country's education. The low quality and relevance of education is also caused by the low quality of teaching staff. Assessment can be seen from the learning qualifications that can be achieved by the teacher.

Based on observations when peer tutoring activities were routinely carried out at the Santa Lusia Sei Rotan Private Junior High School, it was found that the majority of teachers had not made learning preparations in accordance with the principles of the K13 curriculum (PAIKEM learning). Among them are not using a varied learning model and tend to use the lecture method, the still weak learning preparation process, the lesson plans that are designed are not in accordance with the situation and environmental conditions, resulting in the low absorption of students. And in the learning process in class students are less motivated to think creatively and innovatively, students are only stuffed with rote memorization so they don't understand the problems they face.

Teachers play an important role in the educational process in schools. Therefore, to improve the quality of education, it is first necessary to improve the quality of teachers continuously.

The quality of learning always refers to the fulfillment of the eight National Education Standards. In this case, the quality of learning is closely related to the eight components of the National Education Standards: (1) comprehensive intelligent graduates, (2) dynamic curriculum according to the needs of the times, (3) student-oriented learning process and developing student creativity, (4) process learning is equipped with an educational assessment and evaluation system that is reliable, valid and fulfills the principles of assessment, (5) Professional teachers and education personnel are experienced and can be role models, (6) The facilities and infrastructure used are complete and in accordance with local wisdom, ( 7) Accurate and reliable management system, (8) Effective and efficient education financing (Ridwan Abdullah Sani 2015: 1). The quality of learners must refer to the principles of quality achievement, namely: (1) customer satisfaction, (2) respect for everyone, (3) management based on facts, and (4) continuous improvement (Dr. H. Oding Supriadi, M.Pd: Pengantar Manajemen Pendidikan, 2018)

\section{RESEARCH METHOD}

This research focuses on the development of educators to improve the quality of learning in Santa Lucia Private Junior High School. In connection with that, the type of research presented is the type of School Action Research (action research) because it wants to reveal or get an in-depth picture of the development of educators to improve the quality of learning in Santa Lucia Private Junior High School.

This research is classified as school action research, with four main steps, namely: planning of coaching actions with learning model workshops, implementation of workshop actions, observations (observations), and reflections after conducting workshops, involving all teachers at Santa Lusia Sei Rattan Private Junior High School. The research was carried out in two general stages, namely the implementation of the workshop and observing the implementation of the workshop activities and their impact on students. The performance indicator set is the increasing ability of teachers to apply learning models in particular, the Inquiry learning model through workshops. Aspects measured in observation are the implementation of Inquiry-based learning model workshops or how to apply learning models, interaction of students with teachers in the teaching and learning process, interaction with students in particular to build critical and creative thinking as one of the characteristics of the learning model. Inquiry based.

In accordance with the design of school action research (school action research) according to Mulyasa (2009:17), researchers need to pay attention to three things which include: planning, implementation, and implications. Furthermore, Mulyasa (2009:9) says that school action research is an effort to improve the performance of the education system, and develop school management to be productive, effective, and efficient. The research procedure is a series of research carried out step by step from start to finish. This procedure is further divided into four stages, namely: planning, implementation, observation / observation and reflection.

Data collection procedures and techniques used are as follows: 1. interview method: interview is a conversation carried out by both parties where the interviewer who held the question and the interviewee gave the answer to the question. The type of interview used is a limited interview, namely a direct meeting between researchers, in this case me as a researcher and key informants, namely educators or teachers at Sei Rotan Private Junior High School and students. 2. Observation method: This method is used to get complete information and want to 
find out the situation before doing the workshop and after doing it. It is important to find out whether the Inquirybased learning model workshop really improves the quality of learning in Sei Rotan Private Junior High School. Observations made during the Inquiry-based learning model workshop. In addition, data collection was carried out by researchers systematically without limiting themselves as pure observers from outside but also being involved in the condition of the subject so that researchers also felt what was felt and lived by the subject. 3. Documentation study: documentation technique is a way of collecting data through data related to this research problem. This method is only a complementary method. Especially the documentation of the development of the Santa Lucia Sei Rotan Private Junior High School, specifically documents related to educators or teachers.

Next, analyze the data after collecting data by observing all the data found through interviews, questionnaire analysis and document studies. This data analysis began after making observations during the Inquiry-based learning model workshop process and its implementation in classroom learning after conducting the workshop and the impact on students.

In analyzing the data about the teacher's ability to apply the inquiry-based learning model, data analysis was used with the percentage analysis technique of teacher learning tools. The percentage technique is used to see what percentage of the teacher's ability to apply the inquiry-based learning model is. As for the supporting data, photo documentation is used during the implementation process.

To get the results of the calculation of the percentage assessment of the observation analysis of the inquirybased learning model, the analysis of the teacher's ability to use the inquiry-based learning model and the analysis of the assessment instrument and determine the value acquisition in each cycle, the formula according to Endrayanto and Harumurti (2014: 292) is used:

$$
\text { Score }=\frac{\text { the number of scoring scores obtained }}{\text { Score maximum }}
$$

By value category:

$$
\begin{array}{ll}
90-100 & =\text { Very good } \\
80-89 & =\text { Good } \\
70-79 & =\text { Enough } \\
60-69 & =\text { Not Enough } \\
\text { NA<60 } & =\text { Very Less }
\end{array}
$$

\section{RESULTS AND DISCUSSION}

\subsection{Teacher Guidance Through PKB}

Teachers as professionals have very important functions, roles and positions. Therefore, the teaching profession must be respected and developed as a dignified profession as mandated in Law Number 14 of 2005 concerning Teachers and Lecturers. The consequence of the teacher as a profession is Continuing Professional Development (PKB). Mastery of competence and application of teacher knowledge and skills, will determine the achievement of the quality of the learning process or guidance of students, and the implementation of additional relevant tasks for schools, and for teachers. The Teacher Professional Development System is an assessment system designed to identify the ability of teachers to carry out their duties through measuring the mastery of competencies shown in their performance. PKB teachers, are the main vehicle in an effort to bring about the desired changes related to student success so that students have more knowledge, have better skills, and show a deep understanding of the teaching material and are able to show what they know and are able to do. PKB includes various ways and/or approaches in which teachers continuously learn after receiving initial education and/or training as teachers. $\mathrm{PKB}$ is carried out through an approach that begins with planning activities, then implementation, evaluation, and reflection designed to improve the characteristics, knowledge, understanding, and skills as shown in Figure 1. PKB is intended to achieve professional competency standards, especially for teachers who have not reached the standard. competence in accordance with the results of the performance appraisal

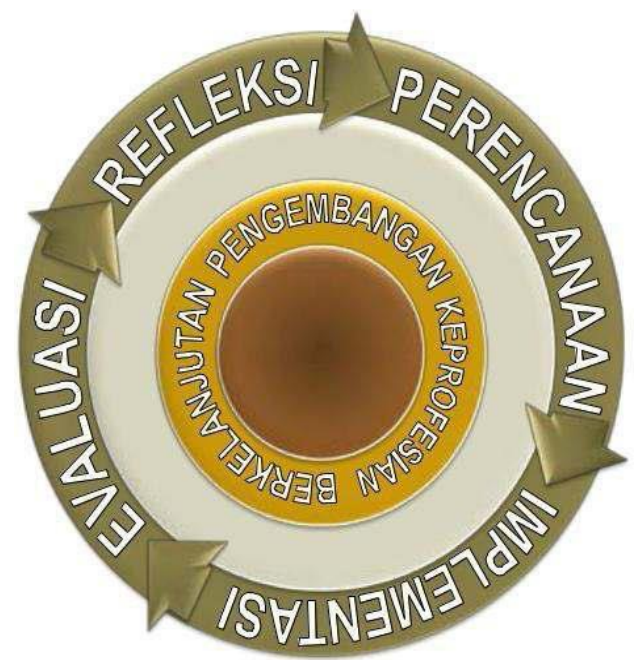

Figure 1. PKB activity diagram

\subsection{Teacher Development: Pedagogic, Personality, Professional and Social Competencies}

Based on PP No. 19 of 2005 concerning National Education Standards Article 28, it is emphasized that educators are learning agents who must have four types of competencies, namely pedagogic, personality, professional and social competencies. The development of basic competencies of education/educational staff must be one of the main programs at every level of 
education. Basic competencies are urgent because they will have an impact on the quality of learning in schools. And the development of the competence of educators must be planned and not only left to each individual while schools or foundations only pay attention to the adequacy of their welfare. Regarding this, Arif Rahman emphasized "the problem of improving the quality or quality of education personnel can not only be solved by providing adequate salaries and welfare, but efforts to develop the competence of educational staff need to be made, this is very important because changes in science and technology are very fast, thus demanding educational staff constantly "absorb" themselves so that they can follow or even create a technological engineering that is beneficial for students or for the lives of the wider community" (Arif Rahman: Professional Development of Vocational Teachers, Qualitative Studies at Vocational Schools in Bandung). The coaching and development of these basic competencies includes: pedagogic, professional, personality and social. Pedagogic competence is the ability to manage student learning which includes understanding students, designing and implementing learning, evaluating learning outcomes, and developing students to actualize their various potentials. Personal competence is a personality ability that is steady, stable, mature, wise, and authoritative, being an example for students, and having noble character. Professional competence is the ability to master learning material broadly and deeply which enables it to guide students to meet the competency standards set out in the National Education Standards. Social competence is the ability of educators as part of the community to communicate and interact effectively with students, fellow educators, parents/guardians of students, and the surrounding community.

\subsection{Coaching Through Inquiry-Based Learning Workshops}

According to Joyce et al. (2016), the inquiry learning model is designed to bring students directly into the scientific process through exercises that can condense the scientific process into a short period of time. The goal is to help students develop the intellectual skills necessary to ask questions and find answers out of curiosity. Inquiry-based learning includes the process of posing problems, obtaining information, thinking critically about the possibility of solving problems, making decisions and conclusions.

Inquiry-based learning is a teaching model that has been developed for the purpose of teaching students how to think. Two main planning tasks are required in preparing inquiry-based learning: 1) setting goals and identifying appropriate problems for inquiry. The teacher wants students to gain new knowledge related to the focus of inquiry from the teaching, wants students to learn the processes of inquiry, especially those related to scientific inquiry, and to develop a positive disposition towards inquiry and the processes used to investigate the socio-political world, 2) identify problem situation or question to trigger an inquiry, the issue must be raised as a non-conforming event

Basically an inappropriate event is a situation that confuses and surprises students, triggers their curiosity, and motivates them to engage in inquiry (Arends, 2012). Inquiry learning means a series of learning activities that involve maximally all students' abilities to search and investigate systematically, critically, logically, analytically, so that they can formulate their own findings confidently. The main targets of inquiry learning activities (Trianto, 2018) are as follows. 1. Maximum student involvement in the process of learning activities 2. Direction of activities logically and systematically in the learning objectives 3 . Developing students' selfconfidence about what is found in the inquiry process. It is necessary to apply inquiry-based learning so that students can compete in life in the future. Inquiry learning can foster students' independence in learning and make them actively investigate or learn to solve problems related to issues that are relevant and meaningful to students. Research shows that students who study in depth will be able to develop their knowledge in the future, compared to students who know information superficially who are unable to solve complex problems (Sani, 2019).

Based on the explanation above, the inquiry learning model is a process of character building students through the search and find method aimed at obtaining information that can solve a problem, where students are involved mentally and physically to solve an accepted problem.

With the understanding of concepts obtained based on experience and can develop critical thinking skills through the results of their findings so that in the end foster an attitude of independent learning in students.

\subsection{Theory Underlying the Inquiry Learning Model}

\subsubsection{Jean Piaget's Theory of Learning}

Swiss psychologist Jean Piaget (Arends, 2012) developed a theory about the human way develop and make sense of the world. The main contribution of Jean Piaget's ideas for teachers is the theory of stages of cognitive development. According to Piaget, when children grow into adults, they go through four stages of cognitive development: sensorimotor, pre-operational, concrete operational, and formal operational. These stages and the types of thinking associated with each stage are described in Table 1. Piaget also provided a theory for understanding how people adapt to their environment through processes of assimilation and accommodation. When people experience new ideas or new situations, they first try to make sense of the new 
information using existing schemata. Remember, schemata refer to the way people store and organize knowledge and experiences in memory. Trying to make sense of new information by adapting it to what we already know is called assimilation. If individuals cannot fit the new data or situation into the existing schemata, they must develop a new concept or schemata, this is called accommodation.

Based on Piaget's theory of cognitive development, learning must pay attention to the arrangement of new knowledge that will be given to students in the form of a problem that can trigger cognitive conflict, so that students will carry out the process of finding a balance between what they feel and know on the one hand and what they know. they see as a new phenomenon. Students try to relate one data to another and match the knowledge they already have, an assimilation process occurs. Meanwhile, when students cannot combine the data they have just received with their knowledge according to their needs, the accommodation process occurs.

Table 1. Piaget's Stages of Cognitive Development

\begin{tabular}{|l|l|l|}
\hline \multicolumn{1}{|c|}{ Stage } & \multicolumn{1}{|c|}{ Age } & \multicolumn{1}{|c|}{ Types of thinking skills } \\
\hline Motor Sensor & Birth 2 years & $\begin{array}{l}\text { Begins to recognize } \\
\text { objects; able to imitate }\end{array}$ \\
\hline Pre-operation & $2-7$ years & $\begin{array}{l}\text { Develop the use of } \\
\text { language; begin to be } \\
\text { able to think } \\
\text { symbolically; can see } \\
\text { other people's point of } \\
\text { view; have no logical } \\
\text { mental operations at this } \\
\text { stage. }\end{array}$ \\
\hline $\begin{array}{l}\text { Concrete } \\
\text { Operations }\end{array}$ & $7-11$ years old & $\begin{array}{l}\text { Can solve real problems } \\
\text { in a logical way }\end{array}$ \\
\hline $\begin{array}{l}\text { Formal } \\
\text { operations }\end{array}$ & years/adult & $\begin{array}{l}\text { Can solve abstract } \\
\text { problems in a logical } \\
\text { way; have a concern for } \\
\text { social problems }\end{array}$ \\
\hline
\end{tabular}

\subsubsection{Bruner's Theory of Learning (Discovery Learning)}

The learning theory of Jerome Bruner, an American psychologist known as discovery learning. Bruner considers that discovery learning corresponds to the active search for knowledge by humans, and by itself gives the best results. truly meaningful (Trianto, 2018). Bruner has also provided a conceptualization of how students learn in stages different maturity. Bruner identifies three modes of learning, namely: . Learning by doing is called activation mode 2 . Learning by forming mental images, which is called iconic mode 3 . Learning through a series of symbols or abstract representations, called symbolic mode (Arends, 2012).

\section{CONCLUSION}

The success of learning in schools cannot be separated from the absolute competencies that teachers must have to support their ability to teach as their duties. The development of the competence of educators must be planned and not only left to each individual while schools or foundations only pay attention to the adequacy of their welfare. Inquiry-based learning is one of the learning models that has been developed for the purpose of teaching students how to think creatively when facing problems or facing problems.

In this inquiry-based learning model workshop, educators or teachers are expected to be able to help students better understand and master the teaching material and in turn students are accustomed to think critically and creatively on any problems or problems that arise. In this regard, the process of fostering and developing educators becomes important and decisive in achieving the goals of quality school education. The development of educators is a strategic factor for improving the quality of education with various efforts in the context of developing integrated human resources (HR).

\section{REFERENCES}

[1] Abdul Sani,R,Isda Pramuniati,Anis Muktiany, 2015. Penjaminan Mutu Sekolah. Jakarta: Bumi Aksara.

[2] Anam Khoirul, M.A. 2015. Pembelajaran Berbasis Inkuiri,Yogyakarta: Pustaka Pelajar.

[3] Arriends, R. 2012. Learning To teach, Ninth Edition. New York: Graw Hill

[4] Arriends. 1997. Model - model Pembelajaran Inovatif Berorientasi Kontuktivistis. Jakarta: Pustaka Publiser.

[5] Balesman, A. dan Mappa, S. 2011. Teori Belajar Orang Dewasa. Jakarta: Rosda Legiman.

[6] Dimyati dan Mudjiono. 2013. Belajar dan Pembelajaran. Jakarta: Rinneka Cipta.

[7] Dimyati dan Mujiono 2009. Belajar dan Pembelaran. Jakarta. Rinneka Cipta.

[8] Engkoswara. 2015. Administarasi Pendidikan. Bandung: Alfabeta

[9] Faturrohman,, M. 2015. Model - model Pembelajaran Inovatif. Yogyakarta: Ar-Ruzz Media. 
[10] Hikmat. 2014. Manajemen pendidikan. Bandung: Pustaka Setia

[11] Hosman, M. 2014. Pendekatan Saintifik dan Kontekstual dalam Pembelajaran abad 21. Kunci Sukses Implementasi Kurikulum 2013. Jakarta: Ghalia Indonesia.

[12] Huda. M. 2014. Model - model Pengajaran dan Pembelajaran Isu-isu Metodis dan Paradigmatis. Yogyakarta. Pustaka Pelajar.

[13] Huda. M.2013. Model-model Pengajaran dan Pembelajaran. Isu-isu Metode dan Paradigmatis. Yogyakarta. Pustaka Pelajar.

[14] Ma'arif dan Tanjung. 2003. Manajemen Operasi. Jakarta: Grasindo

[15] Moleong. 2008. Metodologi Penelitian Kualitatif. Bandung: PT Remaja Rosdakarya

[16] Piaget, Jean.2005. The Psychology of Inteligence.London : Routledge 